\title{
Sistem Pemantauan Energi Listrik Rumah Pintar Berbiaya Rendah
}

\author{
R. Rohmiyati ${ }^{1}$, Muhammad Syafei Gozali ${ }^{1}$, dan Heru Wijanarko ${ }^{1 *}$ \\ ${ }^{1}$ Politeknik Negeri Batam, Jurusan Teknik Elektro, Batam \\ ${ }^{\star} E$-mail: wijanarko@polibatam.ac.id
}

\begin{abstract}
Abstrak
Penelitian ini bertujuan mendesain dan menerapkan pada purwarupa dari sebuah sistem yang dapat memantau penggunaan energi listrik. Sistem pemantauan energi listrik ini berbiaya rendah dengan memanfaatkan perangak loT seperti NodeMcu, Raspberry, Arduino, Wireless Router, dan sensor arus ACS712. Microcontroller Arduino menerima data dari sensor arus ACS712 dan oleh nodeMcu data tersebut dikirm ke server melalui internet. Hasil percobaan menunjukkan bahwa sistem pemantauan energi yang dikembangkan dapat berhasil merekam dan menampilkan pada laman web data tegangan, arus, faktor daya, daya aktif dan konsumsi daya akumulatif.
\end{abstract}

Kata kunci: Perangkat loT, Monitoring, Konsumsi daya, Berbiaya rendah

\begin{abstract}
In this research we design and implement the prototype of a system that can monitor the use of electrical energy. This electrical energy monitoring system is low-cost by assembled the loT devices such as NodeMcu, Raspberry, Arduino, Wireless Router, and ACS712 current sensor. The Arduino microcontroller receives data from the ACS712 current sensor and by nodeMcu the data is sent to the server via the internet. The experimental results show that the developed energy monitoring system can successfully record and display on the web page data of voltage, current, power factor, active power and accumulative power consumption.
\end{abstract}

Keywords: IoT devices, Monitoring, Power consumption, Low-cost 


\section{Pendahuluan}

Kebutuhan energi listrik setiap tahunnya akan terus meningkat, sehingga ketersediaan akan energi listrik tentunya akan mengikuti tren kebutuhan tersebut. Penyediaan dan produksi energi listrik setiap tahunnya terus meningkat mulai dari kenaikan $0,67 \%$ sampai dengan kenaikan 7,89\%. Penyediaan produksi energi listrik ini nantinya akan dipergunakan untuk sektor industri, sektor rumah tangga, sektor komersial atau usaha, dan sektor publik atau umum. Akan tetapi dari jumlah pelanggan keseluruhan yang telah disebutkan tadi, sektor rumah tangga merupakan pelanggan terbesar untuk pemakaian energi listrik yaitu sebesar 56.605.260 pelanggan atau 92,54\% [1].

Kebutuhan energi listrik yang terus meningkat dan penggunaannya pada sektor rumah tangga yang sangat tinggi, akan menimbulkan penurunan performa pada energi serta penurunan kualitas energi listrik itu sendiri. Perlu dilakukan langkah untuk memonitor penggunaan energi listrik dan memunculkan kepedulian untuk hemat listrik [2]. Sering terjadi pemborosan dalam penggunaan energi listrik karena pengguna tidak dapat memonitor seberapa besar energi listrik yang digunakannya. Seperti studi [3] yang menyimpulkan, konsumen akan dapat melihat penggunaan energi listriknya secara real-time, sehingga mendorong mereka untuk menggunakan lebih sedikit energi listrik untuk mengurangi tagihan bulanan. Hampir sama dengan $[4,5]$, dimana menyarankan bahwa lebih banyak energi dapat dihemat atau dikurangi di tingkat rumah tangga melalui feedback konsumsi energi listrik secara real-time dibandingkan dengan cara konvensional.

Saat ini, dengan bantuan teknologi, memonitoring penggunaan energi listrik dapat dengan mudah dilakukan. Sebagai contoh adalah produk yang ditawarkan oleh Schneider [6] dan Bosch [7], sistem untuk memonitoring penggunaan energi. Namun, produk yang ditawarkan tersebut membutuhkan biaya dan investasi yang cukup mahal bagi rumah tangga. Studi dan riset sebelumnya [3,5], belum membahas tentang seberapa besar investasi yang dibutuhkan untuk membuat sistem pemantauan energi listrik berskala rumah tangga. Maka dari itu, penulis membuat sebuah sistem monitoring dan manajemen penggunaan energi listrik berbiaya rendah atau berbiaya murah, memanfaatkan beberapa perangkat IoT seperti, NodeMcu, Raspberry, Arduino, sensor arus ACS712, dan Wireless Router. Penulis mengembangkan sistem yang merupakan bagian dari smart home system, yang memiliki kemampuan untuk memanajemen daya agar mengoptimalkan penggunaan listrik pada rumah tinggal. Sehingga dengan pemanfaatan sistem ini, masyarakat dapat lebih efektif dan efisien dalam me-monitoring pemakaian energi listrik dengan akses internet melalui PC (Personal Computer) atau Smartphone dimanapun.

\section{Metode Penelitian}

\section{A. Deskripsi Sistem}

Sistem yang dibangun adalah aplikasi monitoring untuk manajemen daya listrik pada sebuah gedung berbasis web. Bangunan yang digunakan sebagai objek penelitian merupakan prototype dari gedung MRW Polibatam. Sistem monitoring ini dilakukan pada panel hubung bagi instalasi listrik pada gedung. Penelitian ini dimulai dengan pembuatan maket dan instalasi listrik pada maket, selanjutnya dilakukan wiring sensor dan perangkat yang digunakan, hingga bagaimana sensor terhubung ke microcontroller dan dapat mengirim dan menerima data. Secara keseluruhan perangkat yang dugunakan merupakan perangkat dengan harga yang terjangkau. Kemudian, untuk menampilkan seluruh parameter yang dihasilkan oleh sensor, maka diperlukanlah rancangan perangkat lunak yaitu membuat tampilan web serta basis data nya. Parameter yang ditampilkan pada sistem monitoring ini meliputi arus, faktor daya, tegangan, total daya, dan total biaya pemakaian beban listrik. Topologi dari keseluruhan sistem ditunjukkan pada gambar 1 berikut ini.

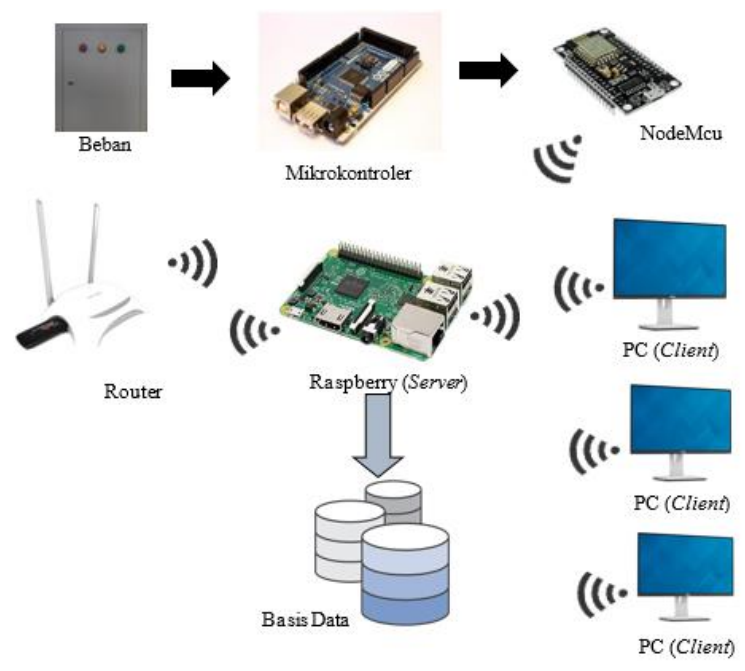

Gambar 1. Topologi Sistem Manajemen Daya 


\section{B. Perancangan Perangkat Lunak}

Perancangan perangkat lunak pada riset ini meliputi perancangan interface website dan basis data sistem monitoring manajemen daya listrik pada gedung. Perancangan perangkat lunak dari web server dengan sistem HTML, PHP, SQL. Semua sistem tersebut difungsikan untuk membangun website. Apabila sistem diminta untuk penggunaan remote atau monitoring jarak jauh, maka pemantauan peralatan rumah dari jarak jauh hanya dengan mengetik link yang ada ke address bar. Ketika akses remote digunakan untuk sistem rumah tinggal, maka parameter atau data-data informasi yang ada pun akan ditampilkan.

\section{Perancangan Database}

Perancangan database pada sistem ini digunakan sebagai tempat penyimpanan data sensor yang diterima dari beban maket. Rancangan database, seperti yang tunjukkan pada gambar 2, menggunakan diagram Entity Relationship Diagram (ERD). Entity Relationship Diagram (ERD) digunakan untuk merancang basis data. Diagram ini dipergunakan untuk memperlihatkan hubungan atau relasi antar entitas atau objek yang terlihat beserta atributnya. Entitas sensor berhubungan dengan Entitas Data_Beban, pada saat data diterima oleh sensor maka data akan disimpan pada Entitas Data Beban dengan atribut (id, ip, volt, cosphi, ampere, waktu) dan akan ditampilkan pada website dengan membaca nilai ip dari Entitas sensor dengan atribut (id, ip, dan Nama_Beban).

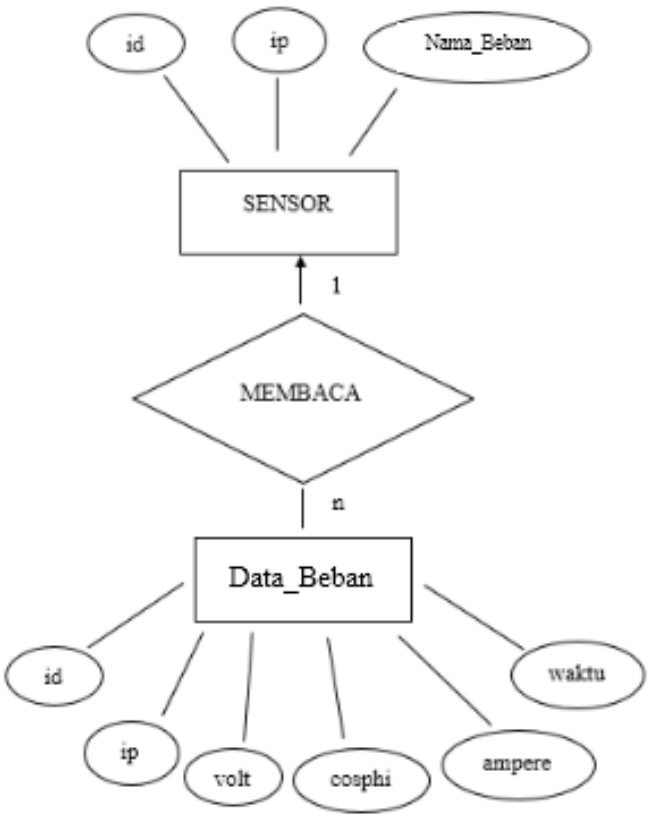

Gambar 2. Rancangan Database

\section{Pembuatan Perangkat Lunak}

Pembuatan perangkat lunak pada riset ini fokus pada tampilan seluruh parameter yang dihasilkan oleh sensor pada aplikasi web dan menyimpan seluruh data yang diterima pada database. Tampilan web untuk panel monitoring ditunjukkan pada gambar 3 .

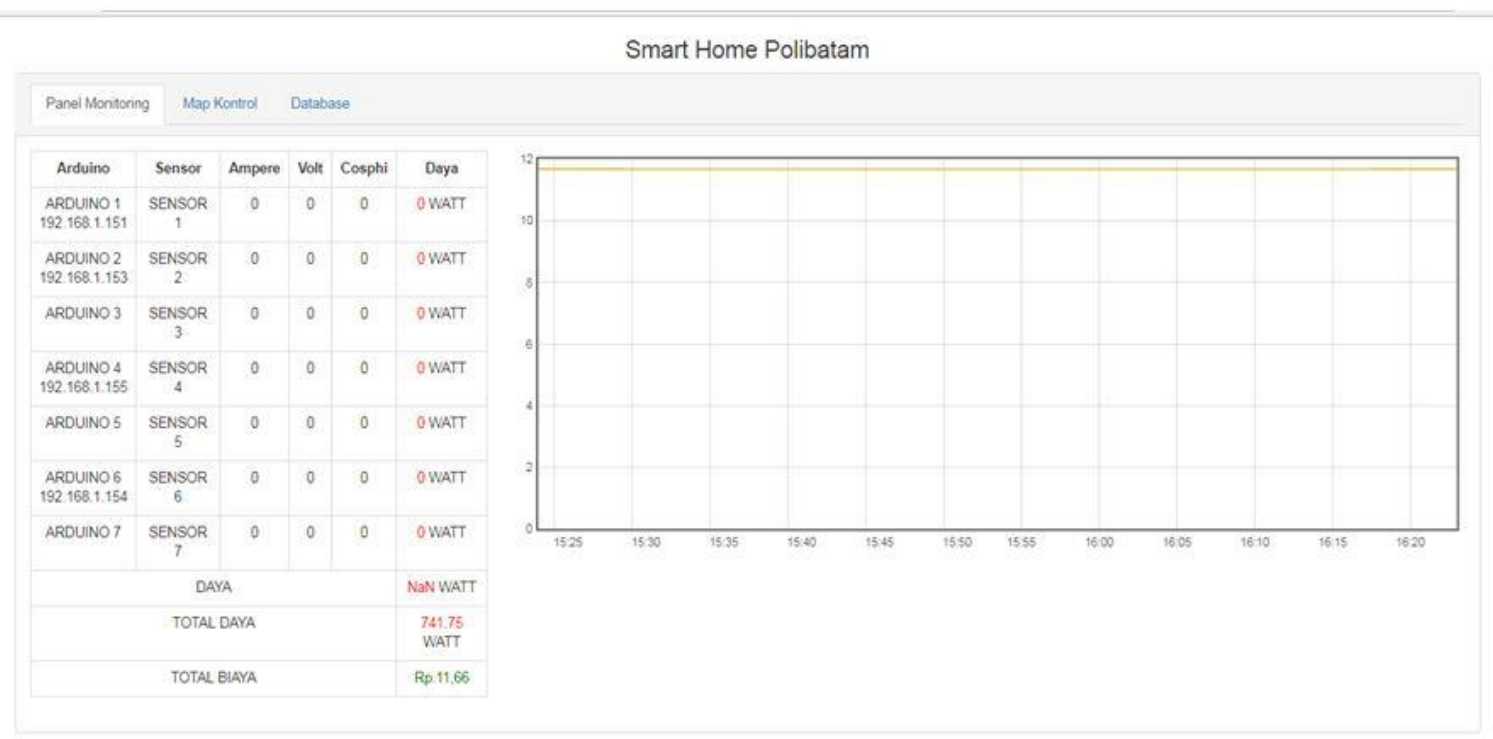

Gambar 3. Tampilan Web untuk Panel Monitoring 


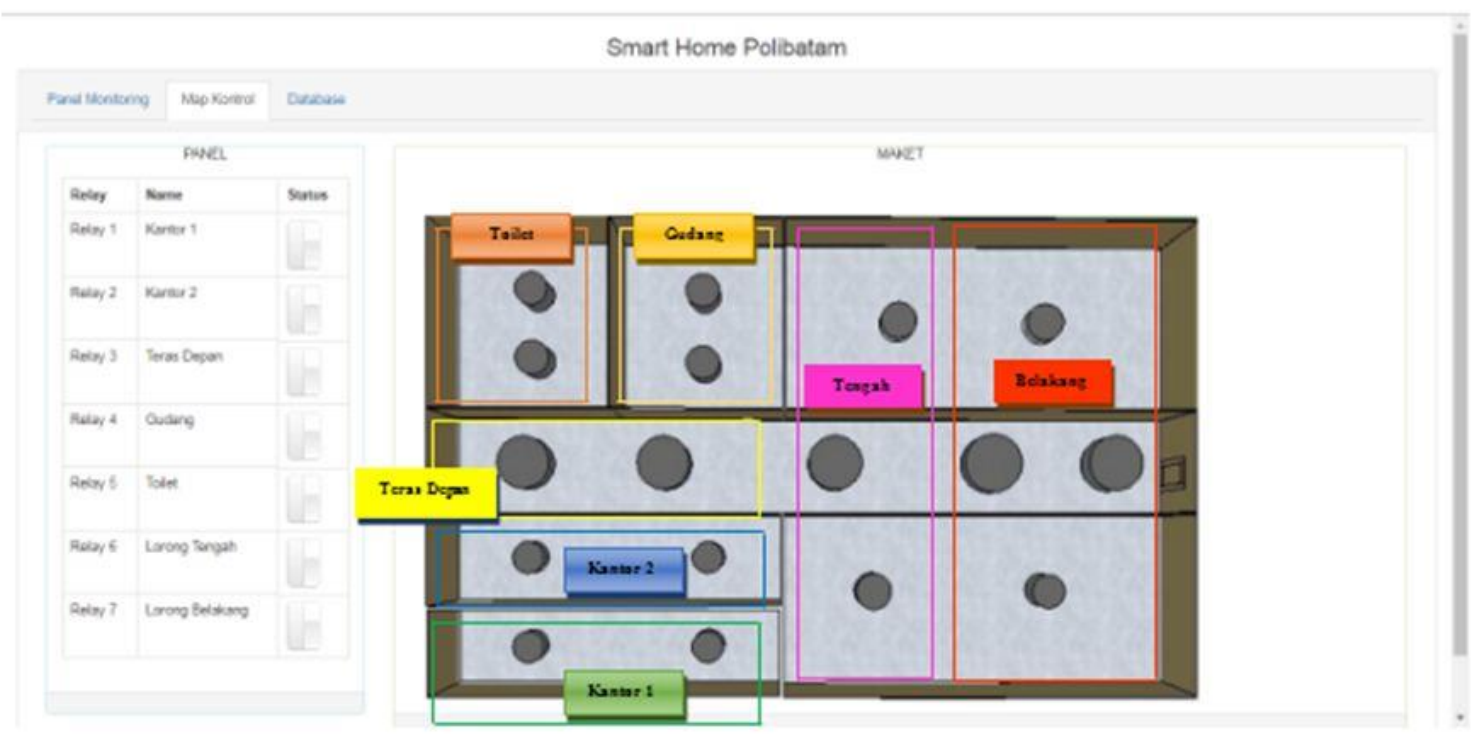

Gambar 4. Tampilan Web Monitoring Status Beban

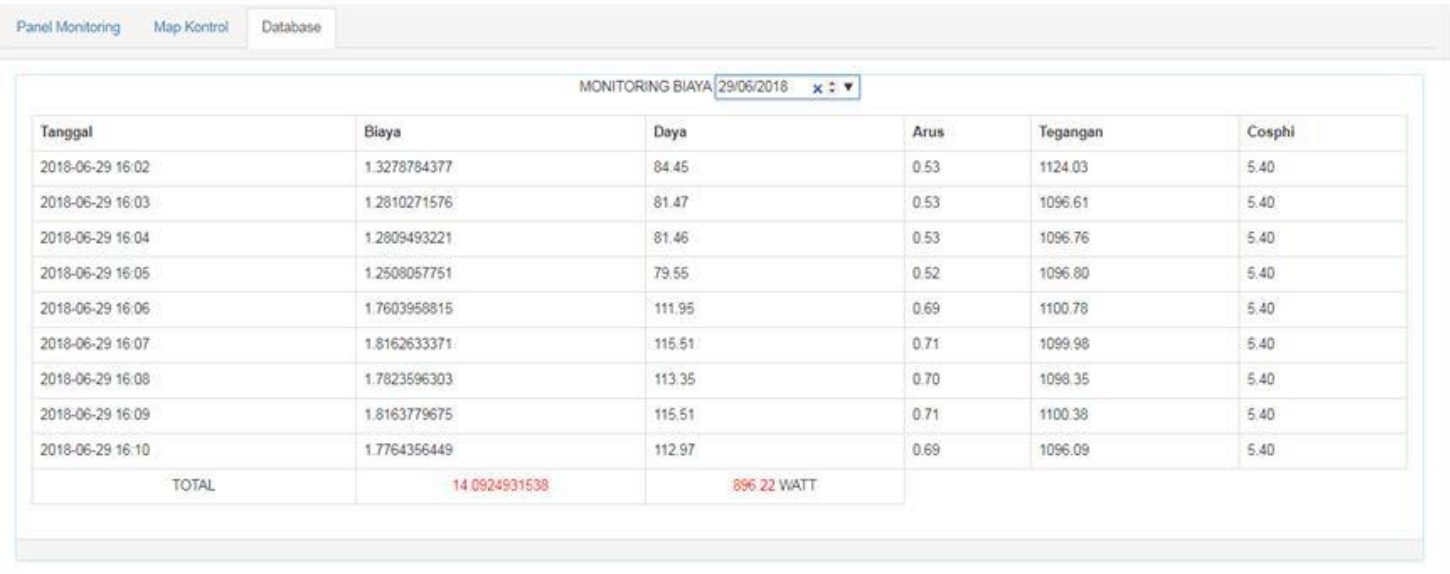

Gambar 5. Tampilan Monitoring Database

Pada tampilan bagian panel monitoring terdapat kolom untuk melihat data sensor yang masuk ketika beban aktif, terdapat kolom total daya, terdapat kolom tarif biaya, dan terdapat grafik antara waktu dengan tarif biaya. Masingmasing ruangan juga di-monitoring status bebannya seperti yang ditampilkan pada gambar 4. Pada tampilan bagian monitoring status beban terdapat button sebagai sakelar dan terdapat gambar visual maket MRW sebagai indikator menyala atau padamnya lampu. Pada saat button sakelar aktif maka visual lampu akan berwarna kuning, dan pada saat button sakelar tidak aktif maka visual lampu akan berwarna hitam.
Sensor akan mengirimkan data ke sistem, saat data terbaca, maka akan dikirimkan ke server melalui komunikasi wireless. Data yang diterima akan disimpan dalam database dan akan ditampilkan pada website seperti yang ditunjukkan pada gambar 5. Pada tampilannya terdapat kolom pilihan tanggal, dan kolom untuk menampilkan arus, tegangan, $\cos \phi$, nilai daya dan biaya setiap tanggal yang dipilih. Apabila data tidak diterima maka data tidak akan ditampilkan pada website dan data tidak akan tersimpan dalam database. Diagram alir dari dari perangkat lunak sistem dapat dilihat pada gambar 6 . 


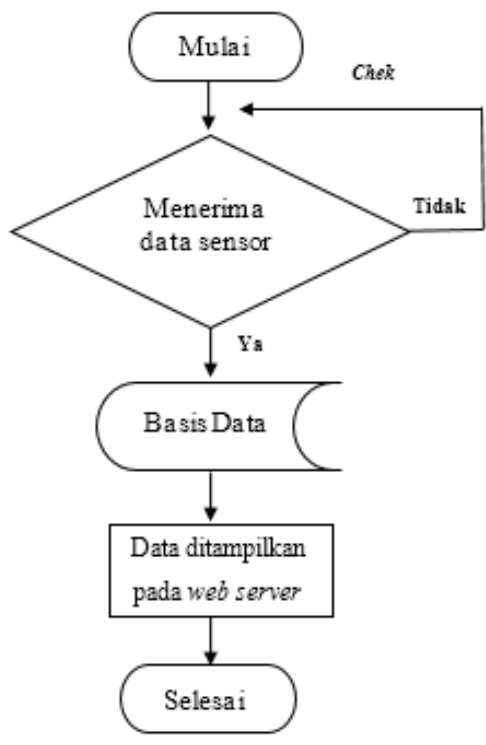

Gambar 6. Flowchart Perangkat Lunak

\section{Hasil dan Pembahasan}

Sistem yang telah dibuat menggunakan beberapa perangkat loT seperti yang ditunjukkan pada gambar 1 . Total biaya yang dihabiskan untuk mikrokontroler (Arduino), NodeMcu, Raspberry, Wireless Router, dan sensor arus ACS712 adalah Rp 850.000 - 1.000.000. Biaya yang dikeluarkan lebih murah jika dibandingkan dengan [8], Clipsal Schneider Electric memasarkan produk serupa dengan harga Rp. 2.000.000 - 2.500.000. Perbandingan lainnya adalah dengan produk Bosch [9], untuk sebuah smart plug dibanderol dengan harga sekitar $\mathrm{Rp}$ 1.000.000 - 1.250.000. Sehingga, jika dibandingkan dengan produk serupa yang telah dipasarkan, sistem yang telah dibuat ini berbiaya rendah dan lebih terjangkau untuk skala rumah tangga.

\section{A. Hasil Pengujian Monitoring Status Lampu}

Pengujian dan pengukuran pada maket MRW dilakukan pada setiap ruangan, yaitu: lampu teras depan; toilet; gudang; kantor 1; kantor 2; lampu tengah; dan lampu belakang.

Pengujian awal yang dilakukan adalah melakukan percobaan apakah data sensor dapat diterima dan ditampilkan pada web. Sebagai contoh, dari tabel 1 untuk lampu teras depan, ditunjukkan bahwa percobaan monitoring status lampu berhasil dilakukan. Lampu dapat dikontrol 22 melalui sakelar maupun melalui web, dan output dari kondisi lampu dapat diketahui melalui web.

Tabel 1. Pengujian Monitoring Status Lampu Teras Depan

\begin{tabular}{|c|c|c|c|c|}
\hline No. & $\begin{array}{l}\text { Kontrol } \\
\text { Sakelar } \\
\text { Manual }\end{array}$ & $\begin{array}{l}\text { Kontrol } \\
\text { dari } W e b\end{array}$ & $\begin{array}{l}\text { Kondisi } \\
\text { Lampu }\end{array}$ & $\begin{array}{l}\text { Tampilan } \\
\text { pada Web }\end{array}$ \\
\hline 1 & OFF & OFF & Padam & Padam \\
\hline 2 & OFF & $O N$ & Menyala & Menyala \\
\hline 3 & ON & $O F F$ & Menyala & Menyala \\
\hline 4 & ON & ON & Padam & Padam \\
\hline
\end{tabular}

Gambar 7 menunjukkan hasil pengujian pada maket saat lampu teras depan pada maket dinyalakan baik secara manual menggunakan sakelar atau secara online, seperti tampilan pada gambar 8 , dengan menekan button pada laman web.

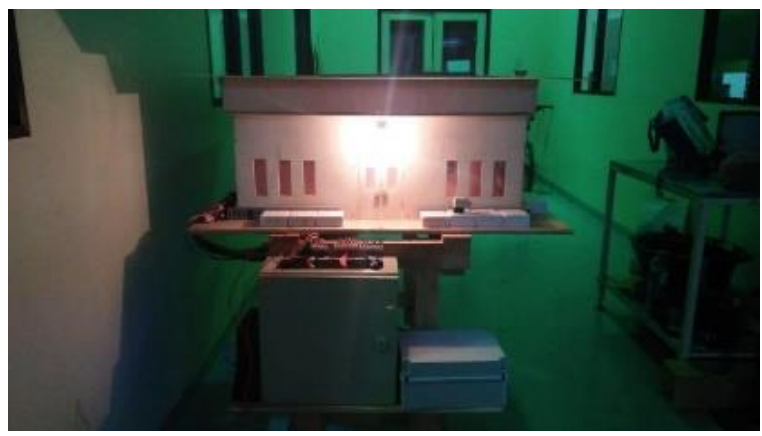

Gambar 7. Dokumentasi Hasil Pengujian pada Maket Lampu Teras Depan

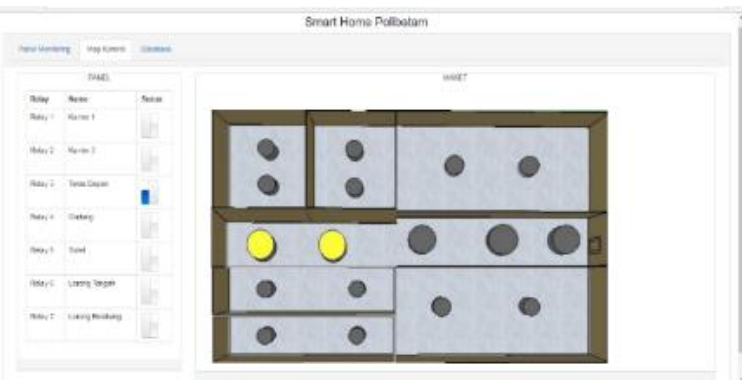

Gambar 8. Tampilan Pengujian Lampu Teras Depan pada Web

Secara keseluruhan, untuk setiap ruangannya, hasil yang didapat dari pengujian yang dilakukan adalah untuk menyalakan lampu, dapat dilakukan dua cara yaitu manual dari sakelar dan secara online dari button pada web. Terlihat pada tabel 1 pengujian pada saat kontrol dari sakelar on dan kontrol dari web bernilai off maka output pada maket keadaan lampu hidup, lalu pengujian pada saat kontrol dari sakelar bernilai off dan kontrol dari web bernilai on maka output pada visual web keadaan lampu hidup. 
Respon perintah untuk mengontrol lampu melalui web tergantung pada kecepatan jaringan internet yang digunakan.

\section{B. Hasil Pengujian Monitoring Pemakaian Daya Listrik}

Pengujian monitoring pemakaian daya listrik dilakukan dengan membagi beban dalam enam skenario beban yang ditunjukkan pada tabel 2. Durasi pengambilan data pada masingmasing skenario adalah 5 menit secara bergantian.

Tabel 2. Skenario Monitoring Pemakaian Daya Listrik

\begin{tabular}{|c|c|c|}
\hline $\begin{array}{l}\text { Skenario } \\
\text { ke- }\end{array}$ & IP Address & Kondisi Beban \\
\hline 1 & 192.168 .1 .151 & $\begin{array}{l}\text { semua beban aktif (teras } \\
\text { depan ( } 15 \text { Watt), kantor } 1 \\
\text { (15 Watt), kantor } 2 \quad(15 \\
\text { Watt)) dalam waktu } 5 \text { menit } \\
\text { pertama }\end{array}$ \\
\hline 2 & 192.168.1.153 & $\begin{array}{l}\text { semua beban aktif (toilet ( } 5 \\
\text { Watt), gudang ( } 5 \text { Watt), } \\
\text { tengah ( } 3 \times 5 \text { Watt), dan } \\
\text { belakang }(3 \times 5 \text { Watt })) \text { dalam } \\
\text { waktu } 5 \text { menit kedua }\end{array}$ \\
\hline 3 & 192.168 .1 .158 & $\begin{array}{l}1 \text { beban solder } 20 \text { Watt dan } \\
1 \text { beban glue gun } 20 \text { Watt } \\
\text { aktif dalam waktu } 5 \text { menit } \\
\text { ketiga }\end{array}$ \\
\hline 4 & 192.168 .1 .155 & $\begin{array}{l}1 \text { beban solder } 20 \text { Watt dan } \\
1 \text { beban glue gun } 20 \text { Watt } \\
\text { aktif dalam waktu } 5 \text { menit } \\
\text { keempat }\end{array}$ \\
\hline 5 & 192.168.1.159 & $\begin{array}{l}1 \text { beban solder } 20 \text { Watt dan } \\
1 \text { beban glue gun } 20 \text { Watt } \\
\text { aktif dalam waktu } 5 \text { menit } \\
\text { kelima }\end{array}$ \\
\hline 6 & 192.168.1.154 & $\begin{array}{l}1 \text { beban solder } 20 \text { Watt dan } \\
1 \text { beban glue gun } 20 \text { Watt } \\
\text { aktif dalam waktu } 5 \text { menit } \\
\text { keenam }\end{array}$ \\
\hline
\end{tabular}

Tabel 3 merupakan pengujian terhadap skenario ke-1 dengan IP Address 192.168.1.151, pengujian ini dilakukan selama lebih kurang 5 menit. Hasil monitoring daya pada skenario 1, dapat dilihat bahwa tegangan terbaca berkisar antara 207.71 Volt hingga 210.36 Volt. Untuk nilai cos phi pada sistem ini ditetapkan sebesar 0,9 . Nilai tersebut didapat dari rata-rata cos phi yang diukur pada dari gedung MRW Polibatam. Sedangkan arus terukur dari data monitoring adalah konstan dengan nilai 0,23 Ampere.

Nilai daya yang ditampilkan pada monitoring merupakan hasil perhitungan dari tegangan dan arus yang terukur, menggunakan persamaan berikut.

$$
W=V \cdot I \cdot \operatorname{Cos} \varphi
$$

Data yang ditampilkan dari monitoring untuk data berada pada rentang 43.00 Watt sampai dengan 43.54 Watt. Dimana daya total yang digunakan pada skenario 1 selama 5 menit adalah 0.0090 kWh.

Tabel 3. Pengujian Monitoring Pemakaian Daya Skenario 1

\begin{tabular}{|c|c|c|c|c|}
\hline $\begin{array}{l}\text { Tegangan } \\
\text { (Volt) }\end{array}$ & $\begin{array}{l}\text { Cos } \\
\text { phi }\end{array}$ & $\begin{array}{c}\text { Arus } \\
\text { (Ampere) }\end{array}$ & $\begin{array}{l}\text { Daya } \\
\text { (Watt) }\end{array}$ & $\begin{array}{c}\text { Waktu } \\
\text { Pengambilan } \\
\text { Data }\end{array}$ \\
\hline 210.19 & 0.90 & 0.23 & 43.51 & $\begin{array}{c}2018-06-29 \\
16: 06: 00\end{array}$ \\
\hline 208.92 & 0.90 & 0.23 & 43.25 & $\begin{array}{c}2018-06-29 \\
16: 06: 10\end{array}$ \\
\hline 208.42 & 0.90 & 0.23 & 43.14 & $\begin{array}{c}2018-06-29 \\
16: 06: 20\end{array}$ \\
\hline 209.56 & 0.90 & 0.23 & 43.38 & $\begin{array}{c}2018-06-29 \\
16: 06: 31\end{array}$ \\
\hline 210.36 & 0.90 & 0.23 & 43.54 & $\begin{array}{c}2018-06-29 \\
16: 06: 41\end{array}$ \\
\hline 209.23 & 0.90 & 0.23 & 43.31 & $\begin{array}{c}2018-06-29 \\
16: 06: 51\end{array}$ \\
\hline 210.06 & 0.90 & 0.23 & 43.48 & $\begin{array}{c}2018-06-29 \\
16: 07: 01\end{array}$ \\
\hline 209.49 & 0.90 & 0.23 & 43.36 & $\begin{array}{c}2018-06-29 \\
16: 07: 11\end{array}$ \\
\hline 209.46 & 0.90 & 0.23 & 43.36 & $\begin{array}{c}2018-06-29 \\
16: 07: 21\end{array}$ \\
\hline 208.20 & 0.90 & 0.23 & 43.10 & $\begin{array}{c}2018-06-29 \\
16: 07: 31\end{array}$ \\
\hline 209.78 & 0.90 & 0.23 & 43.42 & $\begin{array}{c}2018-06-29 \\
16: 07: 41\end{array}$ \\
\hline 209.92 & 0.90 & 0.23 & 43.45 & $\begin{array}{c}2018-06-29 \\
16: 07: 51\end{array}$ \\
\hline 208.43 & 0.90 & 0.23 & 43.15 & $\begin{array}{c}2018-06-29 \\
16: 08: 02\end{array}$ \\
\hline 209.33 & 0.90 & 0.23 & 43.33 & $\begin{array}{c}2018-06-29 \\
16: 08: 12\end{array}$ \\
\hline 208.52 & 0.90 & 0.23 & 43.16 & $\begin{array}{c}2018-06-29 \\
16: 08: 22\end{array}$ \\
\hline 209.13 & 0.90 & 0.23 & 43.29 & $\begin{array}{c}2018-06-29 \\
16: 08: 32\end{array}$ \\
\hline 208.84 & 0.90 & 0.23 & 43.23 & $\begin{array}{c}2018-06-29 \\
16: 08: 42\end{array}$ \\
\hline 209.91 & 0.90 & 0.23 & 43.45 & $\begin{array}{c}2018-06-29 \\
16: 08: 52\end{array}$ \\
\hline 209.44 & 0.90 & 0.23 & 43.35 & $\begin{array}{c}2018-06-29 \\
16: 09: 02\end{array}$ \\
\hline 209.32 & 0.90 & 0.23 & 43.33 & $\begin{array}{c}2018-06-29 \\
16: 09: 12\end{array}$ \\
\hline 209.46 & 0.90 & 0.23 & 43.36 & $\begin{array}{c}2018-06-29 \\
16: 09: 22\end{array}$ \\
\hline 209.91 & 0.90 & 0.23 & 43.45 & $\begin{array}{c}2018-06-29 \\
16: 09: 32\end{array}$ \\
\hline 208.64 & 0.90 & 0.23 & 43.19 & $\begin{array}{c}2018-06-29 \\
16: 09: 42\end{array}$ \\
\hline 208.78 & 0.90 & 0.23 & 43.22 & $\begin{array}{c}2018-06-29 \\
16: 09: 53\end{array}$ \\
\hline 207.71 & 0.90 & 0.23 & 43.00 & $\begin{array}{c}2018-06-29 \\
16: 10: 03\end{array}$ \\
\hline 208.04 & 0.90 & 0.23 & 43.06 & $\begin{array}{c}2018-06-29 \\
16: 10: 13\end{array}$ \\
\hline 208.65 & 0.90 & 0.23 & 43.19 & $\begin{array}{c}2018-06-29 \\
16: 10: 33\end{array}$ \\
\hline 208.52 & 0.90 & 0.23 & 43.16 & $\begin{array}{c}2018-06-29 \\
16: 10: 43\end{array}$ \\
\hline 209.20 & 0.90 & 0.23 & 43.30 & $\begin{array}{c}2018-06-29 \\
16: 10: 53\end{array}$ \\
\hline 209.27 & 0.90 & 0.23 & 43.32 & $\begin{array}{c}2018-06-29 \\
16: 11: 03\end{array}$ \\
\hline
\end{tabular}




\begin{tabular}{lllll}
\hline 209.25 & 0.90 & 0.23 & 43.31 & $\begin{array}{c}2018-06-29 \\
16: 11: 13\end{array}$ \\
\hline
\end{tabular}

Monitoring pemakaian daya listrik yang didapat selama kurang lebih 30 menit jika dijumlahkan maka hasil pemakaian daya listriknya seperti yang ditunjukkan pada tabel 4 .

Tabel 4. Skenario Monitoring Pemakaian Daya Listrik

\begin{tabular}{ccc}
\hline $\begin{array}{c}\text { Skenario } \\
\text { ke- }\end{array}$ & $\begin{array}{c}\text { Total } \\
\text { Pemakaian } \\
\text { Daya (kWh) }\end{array}$ & $\begin{array}{c}\text { Total Pemakaian Daya } \\
\text { Kumulatif } \\
\text { (kWh) }\end{array}$ \\
\hline 1 & 0.0090 & 0.0090 \\
2 & 0.0080 & 0.0170 \\
3 & 0.0069 & 0.0240 \\
4 & 0.0075 & 0.0320 \\
5 & 0.0066 & 0.0390 \\
6 & 0.0063 & 0.0453 \\
\hline
\end{tabular}

Hasil dari moinitoring pemakaian daya listrik pada tabel 4 ditampilkan pada panel monitoring web seperti yang ditunjukkan pada gambar 9 berikut ini.

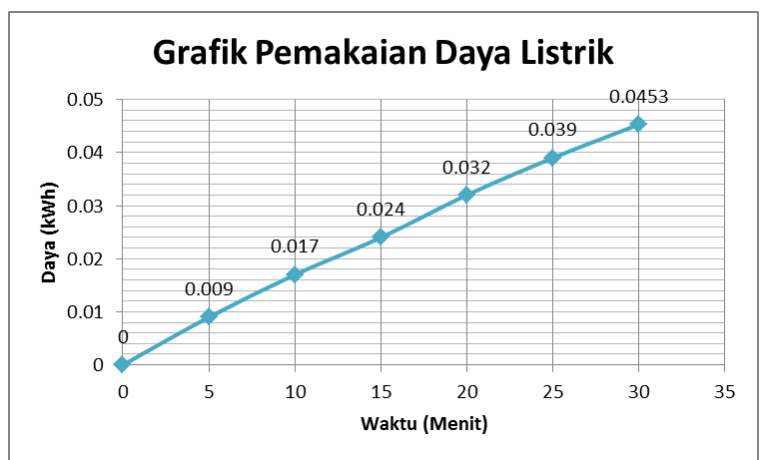

Gambar 9. Grafik Pemakaian Daya Listrik pada Panel Monitoring Web

Dari pengujian yang sudah dilakukan, monitoring untuk pengontrolan lampu menggunakan web sudah dapat dilakukan, kondisi lampu dalam pengujian secara aktual baik dalam kondisi on/off sudah sesuai dengan kondisi visual yang ada pada tampilan web. Dimana respon dari sistem tergantung pada provider internet yang digunakan. Web dapat mengontrol lampu saat raspberry (server) sudah terhubung oleh router dan jaringan internet sehingga program dapat dijalankan.

Tingkat akurasi dari data yang ditampilkan oleh sensor tergantung dari jenis sensor yang digunakan. Seperti pada riset ini menggunakan sensor arus ACS712 yang memiliki tingkat error $1.5 \%$ pada suhu ruangan [10], dimana masih lebih baik jika dibandingkan dengan sensor arus SCT013 [11].

\section{Simpulan}

Berdasarkan hasil pembahasan maka dapat ditarik simpulan sebagai berikut:

1. Dengan memanfaatkan perangkat IoT berbiaya murah seperti raspberry pi; arduino; NodeMcu; dan sensor arus ACS712, monitoring sistem manajemen daya yang berbasis web ini dapat diakses menggunakan jaringan internet.

2. Laman web yang dibuat dapat memantau parameter listrik AC seperti, arus (A) tegangan $(\mathrm{V})$, faktor daya $(\cos \phi)$, dan jumlah daya listrik (kWh).

3. Dengan menggunakan sensor arus ACS712, tingkat akurasi dari akuisisi data parameter yang ditampilkan pada sistem pemantauan energi listrik ini dapat mencapai $99,5 \%$.

\section{Ucapan Terima Kasih}

Ucapan terima kasih disampaikan kepada Program Studi D4 Teknik Mekatronika, Jurusan Teknik Elektro, Politeknik Negeri Batam yang telah mendukung pelaksanaan penelitian ini.

\section{Daftar Pustaka}

[1] "Statistik_Ketenagalistrikan_2015.pdf." Accessed: Mar. 28, 2020. [Öline]. Available: https://www.esdm.go.id/assets/media/conten t/Statistik_Ketenagalistrikan_2015.pdf.

[2] S. Madakam, R. Ramaswamy, and S. Tripathi, "Internet of Things (IoT): A Literature Review," Journal of Computer and Communications, vol. 3, pp. 164-173, Apr. 2015.

[3] A. M. Vega, F. Santamaria, and E. Rivas, "Modeling for home electric energy management: A review," Renewable and Sustainable Energy Reviews, vol. 52, pp. 948959, Dec. 2015.

[4] E. Taktak and I. B. Rodriguez, "Energy Consumption Adaptation Approach for Smart Buildings," in 2017 IEEE/ACS 14th International Conference on Computer Systems and Applications (AICCSA), Oct. 2017, pp. 13701377. 
[5] K. Athira, A. R. Devidas, M. V. Ramesh, and V. P. Rangan, "User centered energy management scheme for smart buildings," in 2017 International Conference on Advances in Computing, Communications and Informatics (ICACCI), Sep. 2017, pp. 1296-1302.

[6] "Smart Home Energy Management \& Monitoring."

https://www.se.com/ww/en/home/smarthome/wiser/energy-management/index (accessed Mar. 28, 2020)

[7] "Energy Manager," Bosch Global. https://www.bosch.com/stories/smart-homeenergy-management-system/ (accessed Mar. 28, 2020).

[8] Clipsal, "4RCBEM2 Wiser Energy by Clipsal Wiser | Clipsal."
https://www.clipsal.com/products/detail?CatN 0=4RCBEM2 (accessed Apr. 23, 2020).

[9] "Clever electrical appliances: Wireless remote control outlet from Bosch Smart Home," Bosch Smart Home. https://www.boschsmarthome.com/en/web/uk/products/smartsystem-solutions/smart-plug (accessed Apr. 23, 2020).

[10] "ACS712 Datasheet (PDF)-Allegro MicroSystems."

https://www.alldatasheet.com/datasheet$\mathrm{pdf} / \mathrm{pdf} / 168326 /$ ALLEGRO/ACS712.html (accessed Mar. 30, 2020).

[11] E. I. Muda, "Perbandingan Data Sensor Arus SCT 013 dan Sensor Arus ACS 712 Pada Pengukuran Arus Listrik AC," Sarjana, Universitas Brawijaya, 2017. 